\title{
Fiordilatte Cheese Fortified with Inulin from Cichorium intybus or Cynara cardunculus
}

\author{
Maria Grazia Melilli ${ }^{1}$ D, Cristina Costa ${ }^{2}$, Annalisa Lucera ${ }^{2}$, Lucia Padalino ${ }^{2}$, Matteo Alessandro Del Nobile ${ }^{2, *(D)}$ \\ and Amalia Conte ${ }^{2}$ (D) \\ 1 National Council of Research, Institute of BioEconomy, Via Paolo Gaifami 18, 95126 Catania, Italy; \\ mariagrazia.melilli@cnr.it \\ 2 Department of Agricultural Sciences, Food and Environment, University of Foggia, Via Napoli, \\ 71121 Foggia, Italy; cristina.costa@unifg.it (C.C.); annalisa.lucera@unifg.it (A.L.); \\ lucia.padalino@unifg.it (L.P.); amalia.conte@unifg.it (A.C.) \\ * Correspondence: matteo.delnobile@unifg.it
}

Citation: Melilli, M.G.; Costa, C.

Lucera, A.; Padalino, L.;

Del Nobile, M.A.; Conte, A

Fiordilatte Cheese Fortified with Inulin from Cichorium intybus or Cynara cardunculus. Foods 2021, 10, 1215. https://doi.org/10.3390/ foods10061215

Academic Editors: Ioan Cristian Trelea

Received: 19 March 2021

Accepted: 25 May 2021

Published: 27 May 2021

Publisher's Note: MDPI stays neutral with regard to jurisdictional claims in published maps and institutional affiliations.

Copyright: (C) 2021 by the authors. Licensee MDPI, Basel, Switzerland. This article is an open access article distributed under the terms and conditions of the Creative Commons Attribution (CC BY) license (https:/ / creativecommons.org/licenses/by/ $4.0 /$ )

\begin{abstract}
The influence of two different types of inulin added to fiordilatte cheese was assessed on product quality during the proper refrigerated storage period. To this aim, the fresh cheese was produced by a pilot plant, adding inulin, either from chicory (low degree of polymerization) or from cardoon (high degree of polymerization), during the stretching phase of the production process. Microbiological stability, sensory acceptability, texture and color changes of fortified dairy food during storage were measured and compared to the control cheese. Results suggest that inulin from different sources, even if characterized by a different degree of polymerization, can keep the texture and color of fiordilatte during storage. Microbiological analyses highlight that inulin seemed to promote a faster Pseudomonas spp. growth; however, the viable cell concentrations were found to be comparable in all the samples after one week. Enterobacteriaceae growth was faster when inulin from chicory was used. Sensory analysis shows that inulin addition to fiordilatte promoted the sensory quality preservation during storage; in fact, the fortified cheese overall quality was found to be always higher $(p<0.05)$ than that of the control sample, thus suggesting that inulin addition to fiordilatte represents a valid strategy for its fiber fortification.
\end{abstract}

Keywords: inulin; fiordilatte cheese; fiber; fortified food

\section{Introduction}

Inulin is a dietary fiber belonging to fructans, used as common ingredient in the food industry, for dairy and bakery products, for beverages and ice cream [1]. It is used for both technological and nutritional properties. The principal sources of inulin are asparagus root, garlic, chicory root, Jerusalem artichoke, cardoon and dahlia tubers, with an inulin content from 15 to $20 \%$ [2-4]. The physico-chemical properties of inulin are strictly linked to the degree of polymerization that represents the size distribution of the polysaccharide chains in the carbohydrate polymer [5]. Non-digestible oligosaccharides of long chain length are more resistant to saccharolytic fermentation and are more slowly biodegradable than compounds of shorter chain, so their fermentation will take a longer time than oligofructose fermentation, resulting in more residual carbohydrate breakdown in the distal colon [6]. Thanks to its proven nutraceutical effect, inulin could be used for novel food design $[7,8]$.

From a technological perspective, inulin is used as a sugar replacer or as fat replacer [9]. In particular, inulin contributes to the enhancement of the mouth-feel, rheological, creaminess, textural and sensory aspects of soft low-fat cheese [5,9]. Different works have described the benefits for human health and the prebiotic effect of inulin, due to the resistance of dietary fiber during digestion [2,9]. Inulin positively controls the intestinal transit, the cholesterol and the triglycerides concentration in the blood and improves the composition of intestinal microflora $[9,10]$. Some researchers highlight that inulin can improve 
the absorption of magnesium and calcium contained in foods, thus decreasing the risk of osteoporosis [10].

In the scientific literature, the effect of inulin on several dairy products such as ice cream [11], fat-free dairy desserts [12], symbiotic Petit-Suisse cheese [13], milk beverages [14], yogurts [1,15] and imitation fresh cheese [16] has been assessed. To the best of our knowledge, no studies were found on the influence of a high degree of polymerization inulin on fresh pasta filata cheese, such as fiordilatte, to enhance its nutritional properties. Fiordilatte is a famous Italian cheese obtained by stretching acidified curd complemented or not by the addition of lactic acid bacteria. The curd is obtained after the coagulation of cow milk by rennet and/or coagulant enzymes. Fiordilatte shows up to $60 \%$ humidity, high fat content and maximum $2 \%$ salt [17].

Fiordilatte fortification could gain great interest because of its advantage, as is the case for many dairy products, is that it may additionally provide essential nutrients (e.g., calcium, vitamins, proteins) and the fortification with other valuable compounds is a natural way to enhance functionality. For example, Angiolillo et al. [17] developed a synbiotic fiordilatte cheese composed of an edible sodium alginate coating as a carrier of probiotic microorganisms and prebiotic fructo-oligosaccharides. To increase protein content and improve the nutritive quality of a fresh pasta filata cheese very similar to fiordilatte, whey protein hydrolysates were proposed by Jeewanthi et al. [18] as a source of bioactive peptides. Other studies proposed selected sources of omega-3, vitamin D and selenium to fortify mozzarella cheese [19-21]. From a more sustainable perspective, some researchers proposed fruit and vegetable by-products to enrich spreadable cheese [22]. Due to its composition, fiordilatte cheese is apparently a good substrate for fortification with natural compounds because nutritionally it is free of fibers [23]. On the basis of these considerations, this study aimed to produce a fortified fiordilatte, comparing inulin from chicory and inulin from cardoon plant, characterized by a different degree of polymerization.

\section{Materials and Methods}

\subsection{Reagents and Standards}

Hydrochloric acid $(\mathrm{HCl}) 3 \mathrm{~N}$ was purchased from LabChem Inc (Zelienople, PA, USA), sodium hydroxide $50 \%(w / w)$ was purchased from J.T. Baker (Deventer, Holland), and $\alpha-$ glucose, fructose, and sucrose were purchased from Sigma-Aldrich (Steinhem, Germany). Deionized (DI) water, Type I reagent grade, $18 \mathrm{M} \Omega-\mathrm{cm}$ resistivity, was obtained by using a Milli-Q system from Millipore (Milford, MA, USA).

\subsection{Inulin}

Inulin from chicory (Chicory intibus) was purchased by Beneo GmbH (Orafti ${ }^{\circledR} \mathrm{HP}$, Mannheim, Germany). The degree of polymerization was $\geq 23$ of fructose units (low DP). Inulin from cardoon plants (Cynara cardunculus) was extracted and purified at the laboratory level as reported by Sillitti et al. [24] and Padalino et al. [25]. Briefly, fresh roots (consisting of both primary and secondary roots) were washed in cold tap water, scraped and ground to a fine powder. $100 \mathrm{~g}$ of the original homogenate was diluted ten-fold with DI water and put in a boiling water bath for $30 \mathrm{~min}$. After cooling to room temperature, the extract was filtered and centrifuged at $3000 \times g$ for $5 \mathrm{~min}$. The inulin extracted was precipitated at $0{ }^{\circ} \mathrm{C}$ overnight. The supernatants were removed and inulin was washed with distilled water and precipitated at $0{ }^{\circ} \mathrm{C}$ overnight. The washing process was repeated until the inulin was white. After the sixth cycle of washing, solutions of inulin were injected in HPAEC PAD to follow the purity. When the baseline of chromatograms appeared clear (threshold accepted under $10 \mathrm{nC}$ ) and the inulin color, determined by colorimeter (Minolta CR 400), had $L^{*}$ values above 85 , inulin was accepted for purification. Furthermore, inulin was lyophilized in sterile Petri dishes and used for fiordilatte production. The humidity in lyophilized inulin was determined in a thermo-ventilated oven at $105^{\circ} \mathrm{C}$, resulting in less than $0.5 \mathrm{~g} / 100 \mathrm{~g}$ of fresh weight. The inulin characterization was performed as follows: $1 \mathrm{~g}$ of the original homogenate was diluted with water $(10 \mathrm{~mL})$ and put in a boiling water 
bath for $30 \mathrm{~min}$. After cooling to room temperature, the extract was centrifuged. A part of this fraction was diluted with distilled water to analyze free sugars (glucose, fructose, and sucrose) and another fraction was hydrolyzed to determine the total fructose amount. The analyses were performed using high-performance anion exchange chromatography with pulsed amperometric detection (HPAEC PAD) (Thermofisher 3000, Sunnyvale, CA, USA), under the conditions described in Padalino et al. [25]. The degree of polymerization was determined on first fraction and the maximum DP was recorded counting the peaks over a threshold of $10 \mathrm{nC}$ of the chromatograms obtained in runs of $120 \mathrm{~min}$ under the following elution conditions: $90 \mathrm{mM} \mathrm{NaOH}$ with $50 \mathrm{mM} \mathrm{Na}$-acetate for $1 \mathrm{~min}$ followed by a linear gradient from 50 to $500 \mathrm{mM}$ Na acetate in $90 \mathrm{mM} \mathrm{NaOH}$ over a $120 \mathrm{~min}$ period with a flow rate of $0.8 \mathrm{~mL} / \mathrm{min}$. The average chain length (mean DP) was calculated as $(\mathrm{F}-\mathrm{f}-0.525 \mathrm{~s}) /(\mathrm{G}-\mathrm{g}-0.525 \mathrm{~s})$, where $\mathrm{F}$ and $\mathrm{G}$ are total fructose and glucose after acid-hydrolysis and $\mathrm{f}, \mathrm{g}$, and $\mathrm{s}$ are the reducing free sugars fructose, glucose, and sucrose before acid hydrolysis. The mean DP of cardoon inulin resulted $\geq 50$ fructose unit.

\subsection{Fiordilatte Production and Packaging}

Fiordilatte cheese was produced using a pilot plant, by direct acidification with lactic acid. At first, $150 \mathrm{~L}$ of raw milk were processed by the pilot plant (MilkyLab, Modena, Italia) located in Foggia, at the Food Technology laboratory of the University. Milk with $3.7 \mathrm{~g} \mathrm{~L}^{-1}$ of fat and $3.45 \mathrm{~g} \mathrm{~L}^{-1}$ of protein was purchased from Granarolo S.p.A. (branch office of Gioia del Colle, Italy) and transported under refrigerated conditions to the laboratory. Cold milk $\left(7.5 \pm 0.5^{\circ} \mathrm{C}\right)$ was acidified with lactic acid solution $(70: 30 \mathrm{v} / \mathrm{v})$ up to $\mathrm{pH} 5.73 \pm 0.02$. For the coagulation phase, the milk was heated $\left(37.5 \pm 0.2^{\circ} \mathrm{C}\right)$ and $0.18 \mathrm{~mL} \mathrm{Kg}^{-1}$ of liquid rennet (CHY-MAX ${ }^{\circledR}$ Plus, CHR HANSEN, Hoersholm, Danimarca, $200 \mathrm{IMCU} / \mathrm{mL}$ ) was added. Subsequently, the whey was removed and the obtained curd split into three parts. In particular, $9 \mathrm{~kg}$ of curd were starched with a stretching machine set at $80^{\circ} \mathrm{C}$ adding $14 \mathrm{~g} \mathrm{Kg}^{-1}$ of $\mathrm{NaCl}$. In this step, $500 \mathrm{~g}$ of inulin from chicory-Cichorium intybus (IC) or inulin from cardoon-Cynara cardunculus (IS), previously solubilized in $1 \mathrm{~L}$ of water, were added to the curd. According to other studies reported in the literature, the incorporation of inulin was made after the draining step of curd to reduce its loss in the whey $[13,26,27]$. Fiordilatte cheese without inulin was also produced as a control sample $(\mathrm{CNT})$. The obtained fiordilatte $(50 \mathrm{~g})$ was cooled in water $\left(16 \pm 1^{\circ} \mathrm{C}\right)$ for $2 \mathrm{~h}$ and then four pieces of fiordilatte cheese were packaged with a brine solution (tap water) in a polypropylene tray, which was closed with a multilayer film (oriented polyamide/polypropylene $75 / 15 \mu \mathrm{m}$ ) on the top by using a thermo-sealing machine (Orved, Musile di Piave, Venezia, Italy). All the fiordilatte samples were stored at $4 \pm 1{ }^{\circ} \mathrm{C}$ for 9 days. Duplicate batches were produced for proper repetition.

\subsection{Texture Analysis}

Fiordilatte cheese samples were uniformly sliced to a thickness of $15 \mathrm{~mm}$. Cylindrical samples (28 mm diameter) were cut from the center of each cheese slice using a circular cutter. Compression tests were conducted using a Texture Analyzer Zwick/Roell model Z010 (Zwick Roell Italia S.r.l., Genova, Italy). An insert plate fixed in the universal work platform $(100 \times 90 \times 9 \mathrm{~mm})$ and compression die plate $(75 \mathrm{~mm}$ diameter $)$ were parallel plates inside which the cylindrical cheese samples were placed. The maximum force $\left(\mathrm{F}_{\max }\right)$ required to compress the cheese sample to a predetermined level of penetration against a rigid back plate using a cylindrical plunger was recorded for each sample tested. Preload of $0.3 \mathrm{~N}$, load cell of $1 \mathrm{kN}$, maximum percentage deformation of $50 \%$ and constant crosshead speed of $100 \mathrm{~mm} / \mathrm{min}$ were the experimental conditions. For each sample, five replicates were performed. Values of $\mathrm{F}_{\max }$ are expressed in $\mathrm{N}$.

\subsection{Color Analysis}

Color in terms of $\mathrm{L}^{*}$ (lightness), $\mathrm{a}^{*}$ (redness/greenness) and $\mathrm{b}^{*}$ (yellowness/blueness) values was determined using a Chroma Meters CR-400 (Minolta Chromameter, Konica 
Minolta Business Solutions Italia Spa, Milan, Italy). The white tile was used as the standard. Measurements were taken in triplicate on the external and internal surface of fiordilatte. Results were recorded as the mean of measurements. Chroma and $\Delta \mathrm{E}$ were also calculated at each sampling time [28].

\subsection{Sensory Analysis}

A quantitative descriptive analysis was used for the comparison of samples (UNI 10957:2003 Sensory analysis-Method to define the sensory profile of foods and beverages). Sensory evaluation was conducted by 7 trained panelists, members of the Food Packaging laboratory of the University. The panel had previous experience in testing cheese before this study; however, the panelists were retrained over 2 days ( 2 sections per day), to decide the appropriate descriptive terms for sensory evaluation. After retraining, the panelists evaluated product firmness, color, odor and ultimately the overall quality [23]. The analysis of the texture was performed by touching the surface of the products with fingers and evaluating the degree of surface fraying with movements from top to bottom of the surface. To judge the overall quality of cheese, the following product characteristics were also taken into account: white porcelain color, smooth surface, tight shut-off, elastic release of buttermilk after cutting, lack of holes and typical milk smell. Each taster evaluated a set of four samples each labeled with a random three-digit code. Samples were stored in the sensory analysis laboratory at room temperature before tasting and the order of presentation was different for each accepted subject, to avoid mutual interference. The tasters, using individual tasting booths in the hall of sensory analysis of the Food Packaging laboratory, were asked to judge the products by using a 7-point scale where a score equal to 4 indicated the threshold for cheese acceptability [29].

\subsection{Microbiological Analyses and $p H$ Determination}

Fiordilatte cheese $(20 \mathrm{~g})$ was diluted in a sterile saline solution $(0.9 \%)$ and homogenized in a blender (Stomacher, International PBI, Milan, Italy). Decimal dilutions of homogenate cheese were made in a saline solution and plated on selective media for the determination of lactic acid bacteria, lactococci, total bacterial count, Enterobacteriaceae and Pseudomonas spp. using the following media (all from Oxoid, Milan, Italy) and conditions: de Man Rogosa and Sharpe agar, supplemented with cycloheximide $\left(0.17 \mathrm{~g} \mathrm{~L}^{-1}\right)$ (Sigma, Milan, Italy) incubated under anaerobic conditions at $37{ }^{\circ} \mathrm{C}$ for $48 \mathrm{~h}$ for lactic acid bacteria; M17 agar, incubated at $37^{\circ} \mathrm{C}$ for $48 \mathrm{~h}$ for lactococci; Plate Count Agar, incubated at $30{ }^{\circ} \mathrm{C}$ for $48 \mathrm{~h}$ for total bacterial count; Violet Red Bile Glucose Agar incubated at $37^{\circ} \mathrm{C}$ for $24 \mathrm{~h}$ for Enterobacteriaceae; Pseudomonas Agar Base, added with SR103 selective supplement incubated at $25{ }^{\circ} \mathrm{C}$ for $48 \mathrm{~h}$ for Pseudomonas spp. A pH meter was used to measure the $\mathrm{pH}$ of fiordilatte samples (Crison, Barcelona, Spain). All the analyses were performed in duplicate on two different samples.

\subsection{Statistical Analysis}

All the experimental data were compared by one-way ANOVA analysis. A Fisher's test, with the option of homogeneous groups $(p<0.05)$, was used to determine thesignificance differences among samples. To this aim, Statistica 7.1 for Windows (StatSoft Inc., Tulsa, OK, USA) was used.

\section{Results and Discussion}

The main findings recorded for each quality parameter were described and discussed in detail, comparing fortified cheese with each other and with control samples.

As regards texture properties, Figure 1 shows the values of $F_{\max }$ obtained for fiordilatte cheese samples. Due to the progressive product hydration [23], the measures started the day after the production and packaging to allow the equilibrium between brine and fiordilatte being established. As can be inferred from the figure, no definitive trend of the Fmax value of experimental cheese samples was observed during storage. The most striking feature of 
the figure is that the CNT samples recorded values of $F_{\max }$ between 10 and $15 \mathrm{~N}$, whilst the IC sample recorded values of $F_{\max }$ between 15 and $20 \mathrm{~N}$ and the IS sample recorded values of $\mathrm{F}_{\max }$ between 20 and $25 \mathrm{~N}$. Therefore, during the entire observation period, the control cheese maintained $F_{\max }$ values lower than those found for the two fortified cheese samples. According to other studies reported in the literature, it is recognized that the physico-chemical properties of inulin tend to modify the texture of dairy products [5]. However, data recorded for samples to which inulin was added are included in the range of standard values of fiordilatte or mozzarella cheese [30,31].

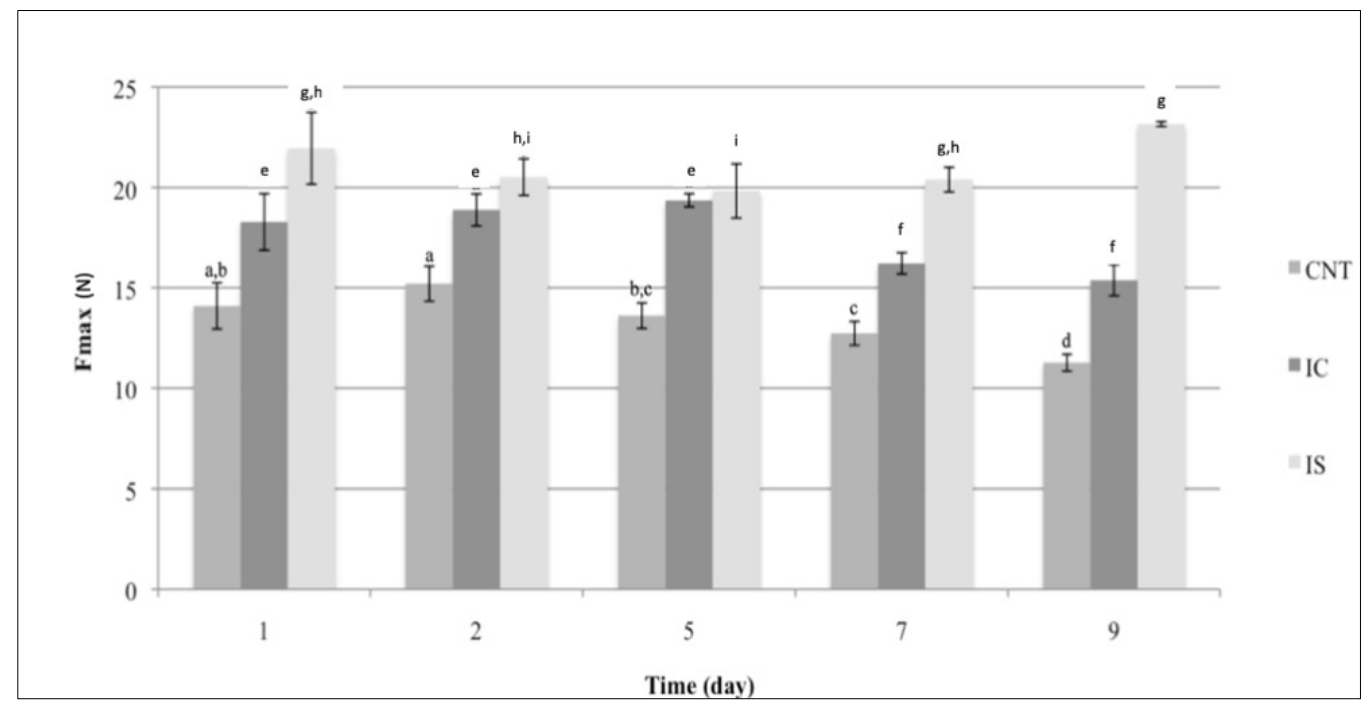

Figure 1. $F_{\max }(\mathrm{N})$ of fiordilatte cheese with inulin from chicory (IC), from cardoon (IS) and without inulin (CNT), during storage time. ${ }^{\text {a-i }}$ Different letters indicate significant differences $(p<0.05)$ within each sample during storage time. Values are means of twenty replications \pm standard deviation.

It is also worth considering that the microbial spoilage and brine presence cause a loss of texture in fiordilatte during storage [23,32]. In this investigation, a marked reduction in $\mathrm{F}_{\max }$ was recorded in the control sample; whereas cheese added with inulin better keeps the initial texture value, above all when inulin with a higher degree of polymerization was used (IS). This difference between the two inulin types can be ascribed to their different degree of polymerization and to the interaction of inulin with water. Tungland and Meyer [33] highlight that the inulin source does not directly influence the water-binding capacity, but it determines the length, particle size and porosity of inulin, thus affecting its physicochemical properties. Other factors such as $\mathrm{pH}$, ionic strength, concentration of inulin and interaction with other water-binding ingredients could also influence textural changes during storage [5].

In Figure $2, L^{*}, a^{*}$ and $b^{*}$ values together with Chroma and $\triangle E$ were reported for all fiordilatte cheese samples (CNT, IC and IS). Data suggest that during the entire storage period, cheese with inulin performed similarly to the control sample, thus confirming that the selected fiber, regardless of its polymerization degree, did not cause any detectable color change to fiordilatte [9].

As long as the color space parameters are concerned, in each sample, some changes occurred during storage, both in internal and external parts of fiordilatte samples. These changes can be ascribed to the brine [23,34] and to the natural physico-chemical spoilage [35], which brings about variations in light values $\left(\mathrm{L}^{*}\right)$ and shift on yellow ( $\mathrm{b}^{*}$ positive) and green (a* negative) axes. In particular, a decrease in the external Chroma values was observed during storage, thus indicating a modification in the color brightness. Small oscillations of the internal Chroma values were also recorded. In terms of Chroma values, differences among cheeses with and without inulin were not significant $(p<0.05)$. 


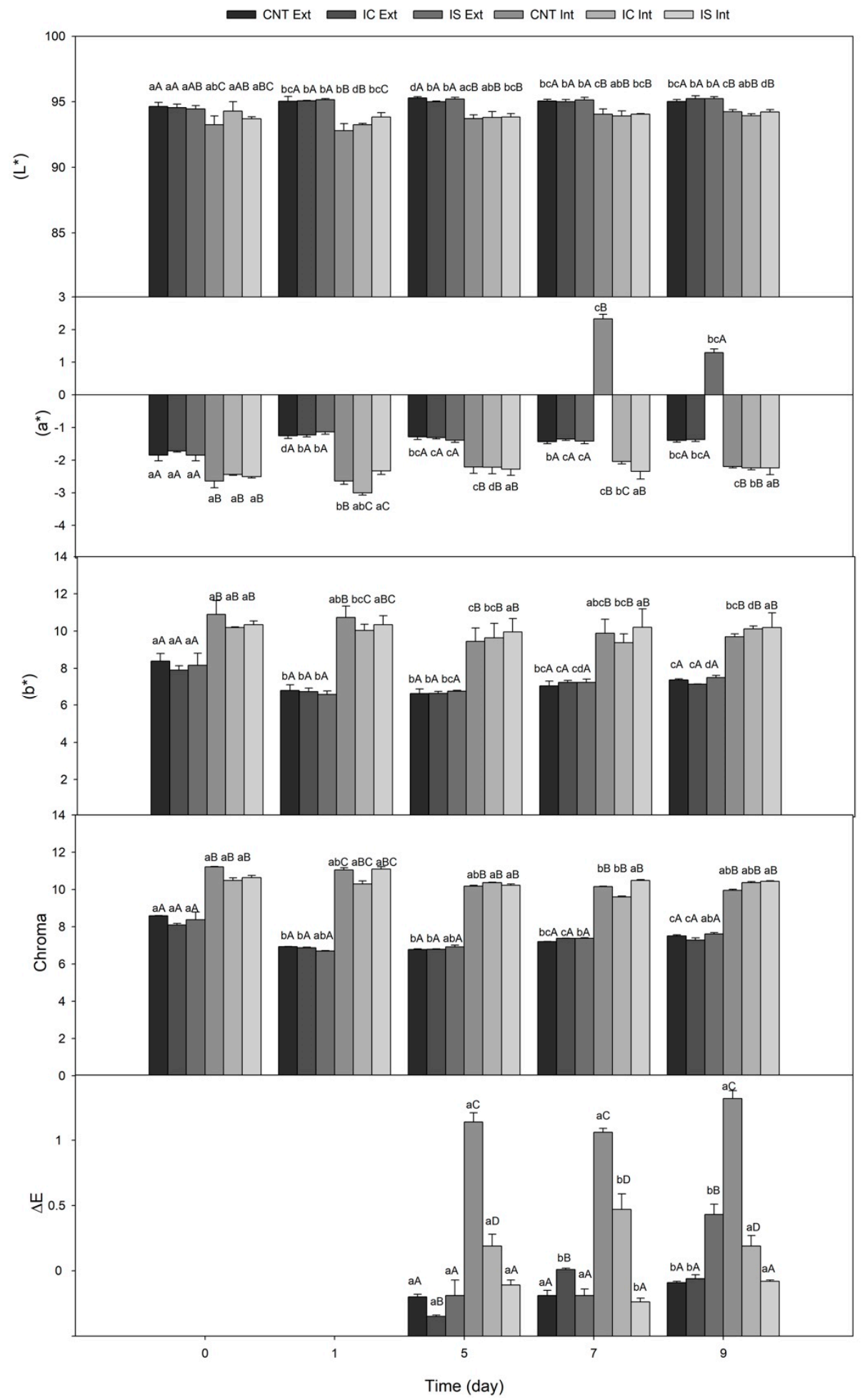

Figure 2. Color parameters $\left(\mathrm{L}^{*}, \mathrm{a}^{*}, \mathrm{~b}^{*}\right.$, Chroma and $\left.\Delta \mathrm{E}\right)$ for external (Ext) and internal (Int) surface of cheese with and without inulin. CNT: control; IC: fiordilatte with inulin from chicory; IS: fiordilatte with inulin from cardoon. Values are means of four replications \pm standard deviation. ${ }^{\text {a-d }}$ Statistical differences at $p<0.05$ among storage times within the same sample; ${ }^{A-D}$ Statistical differences at $p<0.05$ among samples within the same storage time.

$\Delta \mathrm{E}$ indicates the distance in three-dimensional space between the initial $\mathrm{L}^{*}, \mathrm{a}^{*}$ and $\mathrm{b}^{*}$ values. In our study, color changes during storage were observed for both internal and external surfaces of the CNT sample. On the other hand, the addition of inulin reduced 
color changes over time, above all in the internal surface. Among the two inulin types, the lowest internal $\Delta \mathrm{E}$ values were observed for the sample with inulin from cardoon.

In Figure 3, the evolution during the refrigerated storage of the fiordilatte sensory quality as determined by the panel test was reported. Odor, external and internal firmness, together with overall quality are reported. Data on the color are not reported because for this specific attribute, the samples were found all to be equal over time, with scores accounting for 7 for the entire observation period. Therefore, differences recorded from the instrumental color measurement were not revealed by the panel test, who recognized for 9 days in all the sample a good white porcelain color and a smooth cheese surface.

It is worth noting from data reported in the figure that the addition of inulin did not greatly affect the sensory quality of fiordilatte cheese; in fact, comparable scores were recorded between the control and the fortified cheese samples. This result is in accordance with other studies dealing with application of inulin to fresh cheese, that also found a general product acceptance after inulin addition $[9,36]$.

Data in the figure also highlight that, over time, some changes occurred in terms of odor. This finding is not surprising because, according to the literature, the progressive odor alteration is due to the natural spoiling phenomena occurring in dairy products during storage [32,37]. It is worth noting that no differences appear among cheese with and without inulin.

As regards the internal and external firmness of fiordilatte cheese, evident changes were recorded over time. In particular, coherently with what was found in terms of instrumental texture, the panelists observed a progressive softening of the CNT sample, which became unacceptable after 9 days of storage. In contrast, the tasters perceived as acceptable for the entire observation period the internal and external firmness of fiordilatte added with both types of inulin. Considering the trend of sensory attributes, it can be inferred that internal and external firmness are the main responsible factors for differences in fiordilatte overall quality. In fact, as can be observed from data reported in the last part of Figure 3, the IC fiordilatte sample obtained the best results in terms of overall quality between the two tested inulin types. The effect of chicory inulin on the sensory quality could be ascribed to its specific degree of polymerization [9].

Regarding the effect of inulin on the microbiological quality of the investigated cheese, Figure $4 \mathrm{a}, \mathrm{b}$ show the growth of spoilage bacteria (i.e., Pseudomonas spp. and Enterobacteriaceae) in all cheese samples during storage time. A progressive growth of Pseudomonas spp. was observed after cheese packaging in all fiordilatte samples. Specifically, up to 6 days of storage, a higher microbial concentration was found in fortified cheese compared to the control sample.

This finding can be ascribed to the ability of microorganisms to produce inulinase, an enzyme able to degrade inulin in available sugar [38]. After 6 days, the viable cell concentration was similar in all the samples (around $7 \log \mathrm{CFU} \mathrm{g}{ }^{-1}$ ). A similar trend was also observed for mesophylic bacteria (data not shown). Regarding Enterobacteriaceae, a rapid and more pronounced growth was observed in the IC sample, compared to the IS and control cheese, the viable cell count of these two latter remained comparable during the entire period of observation. Between 7 and 9 days, all the samples showed similar microbial growth, accounting for $4-5 \log \mathrm{CFU} \mathrm{g}^{-1}$. A progressive increase in lactobacilli and lactococci viable cell concentration (data not shown) was recorded in all the investigated samples, without statistically significant differences among them (from $2.29 \pm 0.21$ and $3.08 \pm 0.21 \log \mathrm{CFU} \mathrm{g}{ }^{-1}$ to about 5 and $6 \log \mathrm{CFU} \mathrm{g}{ }^{-1}$, for lactobacilli and lactococci, respectively). In terms of $\mathrm{pH}$, no relevant differences were observed among samples (data not shown). For all fiordilatte cheese, small changes from $6.25 \pm 0.01$ to $6.35 \pm 0.03$ were observed. 


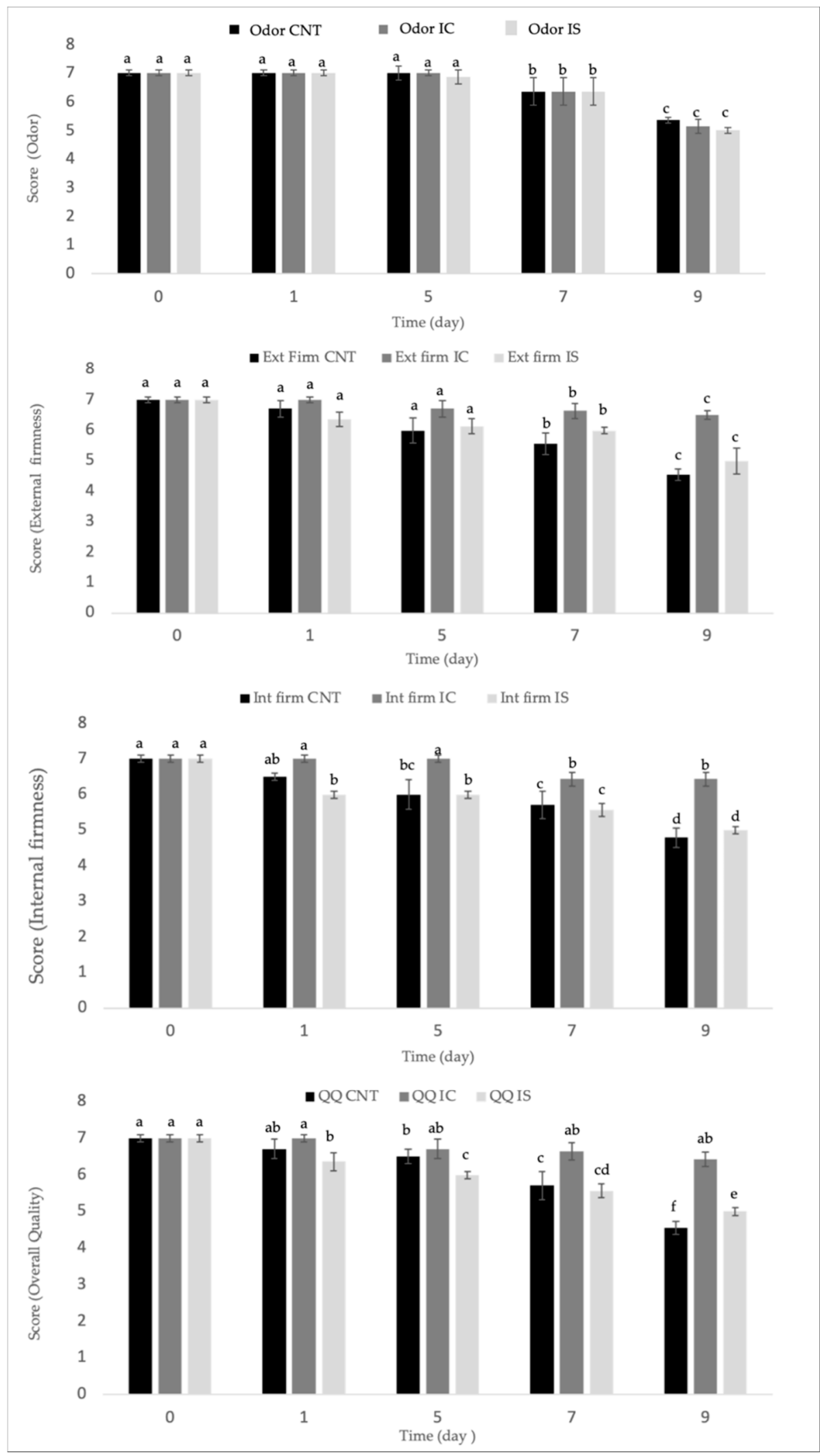

Figure 3. Odor, firmness and overall quality of fiordilatte. Values are means of four replications \pm standard deviation. CNT: control; IC: fiordilatte with inulin from chicory; IS: fiordilatte with inulin from cardoon. Values are means \pm standard deviation. ${ }^{a-f}$ : means of each parameter with different letters are significantly different $(p<0.05)$. 

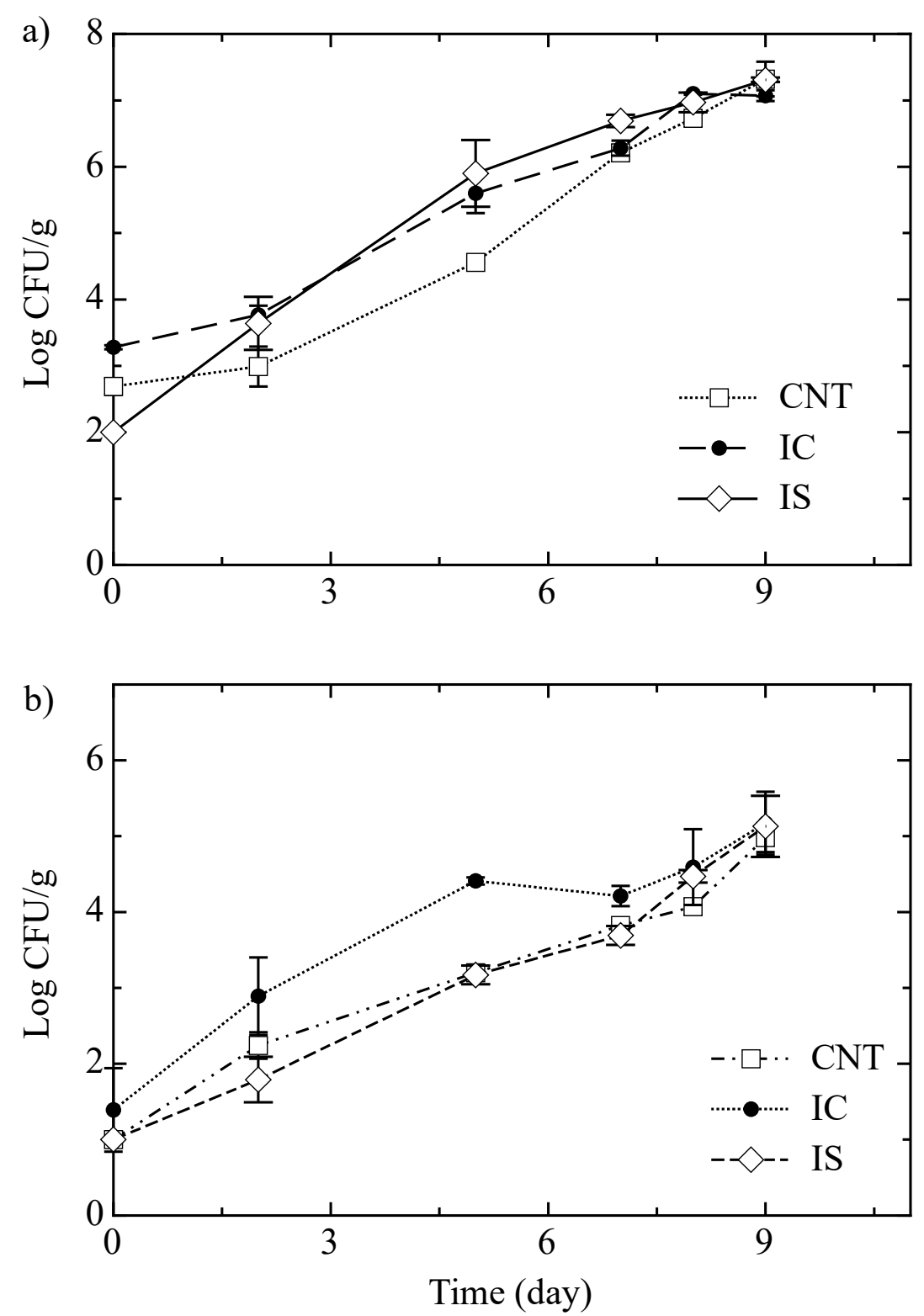

Figure 4. Growth curves of Pseudomonas spp. (a) and Enterobacteriaceae (b) in fiordilatte cheese with inulin from chicory (IC), inulin from cardoon (IS) and without inulin (CNT). Values are means of four replications \pm standard deviation.

\section{Conclusions}

The obtained results suggest that the addition of inulin, regardless of the degree of polymerization, improved the texture characteristics of fiordilatte cheese during refrigerated storage without affecting the odor and color of cheese. Quality parameters measured by instrumental tools were confirmed by the data of sensory quality as perceived by human judges. As far as the microbiological quality is concerned, even though a greater viable cell concentration was observed in the fortified cheese compared to the control sample, in the first days of storage, after about one week, the microbial concentrations were similar in all the investigated samples. Slight differences in product quality between the two types of inulin addition were found. In summary, inulin, from either cardoon plants (IS) or from chicory (IC), improved the texture properties of fiordilatte and reduced internal color changes, thus enhancing the sensory acceptability of cheese during storage. Therefore, the fortification of fiordilatte with natural fiber as inulin can enhance product quality and cheese preservation. 
Author Contributions: Conceptualization, M.G.M., A.C. and M.A.D.N.; methodology, A.C. and M.A.D.N.; product production by pilot plant, C.C., A.L. and M.A.D.N.; formal analysis, C.C., A.L. and L.P.; data curation, M.G.M., A.C. and M.A.D.N.; writing-original draft preparation, C.C., A.L. and L.P.; writing—review and editing, M.G.M., A.C. and M.A.D.N.; supervision, A.C. and M.A.D.N.; funding acquisition, A.C. and M.A.D.N. All authors have read and agreed to the published version of the manuscript.

Funding: This research received no external funding.

Data Availability Statement: The raw data will be made available upon request.

Conflicts of Interest: The authors declare no conflict of interest.

\section{References}

1. Saeed, M.; Iqra, Y.; Pasha, I.; Randhawa, M.A.; Khan, M.I.; Shabbir, M.A.; Khan, W.A. Potential application of inulin in food industry, A review. Pak. J. Food Sci. 2015, 25, 110-116.

2. Kip, P.; Meyer, D.; Jellema, R.H. Inulins improve sensoric and textural properties of low-fat yoghurts. Int. Dairy J. 2006, 16, 1098-1103. [CrossRef]

3. Raccuia, S.A.; Melilli, M.G. Seasonal dynamics of biomass, inulin, and water-soluble sugars in roots of Cynara cardunculus L. Field Crop. Res. 2010, 116, 147-153. [CrossRef]

4. Raccuia, S.A.; Patanè, C.; Melilli, M.G. Multiple utilisation of plants of wild cardoon: Inulin yield. Acta Hort. 2005, 681, 475-482. [CrossRef]

5. Meyer, D.; Bayarri, S.; Tárrega, A.; Costell, E. Inulin as texture modifier in dairy products. Food Hydrocoll. 2011, 25, 1881-1890. [CrossRef]

6. Van De Wiele, T.; Boon, N.; Possemiers, S.; Jacobs, H.; Verstraete, W. Inulin-type fructans of longer degree of polymerization exert more pronounced in vitro prebiotic effects. J. Appl. Microbiol. 2007, 102, 452-460. [CrossRef]

7. Melilli, M.G.; Branca, F.; Sillitti, C.; Scandurra, S.; Calderaro, P.; Di Stefano, V. Germplasm evaluation to obtain inulin with high degree of polymerization in Mediterranean environment. Nat. Prod. Res. 2020, 34, 187-191. [CrossRef] [PubMed]

8. Garbetta, A.; D’Antuono, I.; Melilli, M.G.; Sillitti, C.; Linsalata, V.; Scandurra, S.; Cardinali, A. Inulin enriched durum wheat spaghetti: Effect of polymerization degree on technological and nutritional characteristics. J. Funct. Foods 2020, 71, 104004. [CrossRef]

9. Karimi, R.; Azizi, M.H.; Ghasemlou, M.; Vaziri, M. Application of inulin in cheese as prebiotic, fat replacer and texturizer: A review. Carbohydr. Polym. 2015, 119, 85-100. [CrossRef] [PubMed]

10. Kalyani, K.; Suman, K.N.; Thompkinson, D.K. Inulin dietary fiber with functional and health attributes-A Review. Food Rev. Int. 2010, 26, 189-203. [CrossRef]

11. El-Nagar, G.; Clowes, G.; Tudorica, C.M.; Kuri, V.; Brennan, C.S. Rheological quality and stability of yog-ice cream with added inulin. Int. J. Dairy Technol. 2002, 55, 89-93. [CrossRef]

12. Tárrega, A.; Costell, E. Effect of inulin addition on rheological and sensory properties of fat-free starch-based dairy desserts. Int. Dairy J. 2006, 16, 1104-1112. [CrossRef]

13. Cardarelli, H.R.; Buriti, F.C.A.; Castro, I.A.; Saad, S.M.I. Inulin and oligofructose improve sensory quality and increase the probiotic viable count in potentially symbiotic petit-suisse cheese. LWT Food Sci. Technol. 2008, 41, 1037-1046. [CrossRef]

14. Villegas, B.; Costell, E. Flow behaviour of inulin-milk beverages. Influence of inulin average chain length and of milk fat content. Int. Dairy J. 2007, 17, 776-781. [CrossRef]

15. Guggisbert, D.; Cuthbert-Steven, J.; Piccinali, P.; Bütikofer, U.; Eberhard, P. Rheological, microstructural and sensory characterization of low-fat and whole milk set yoghurt as influenced by inulin addition. Int. Dairy J. 2009, 19, 107-115. [CrossRef]

16. Weiwei, B.; Weili, Z.; Donghua, L.; Xiaodong, L.; Chunyan, Y.; Yongming, Z.; Zhang, Y. Effect of resistant starch and inulin on the properties of imitation mozzarella cheese. Int. J. Food Prop. 2016, 19, 159-171.

17. Jeewanthi, R.K.C.; Lee, N.; Mok, B.; Yoon, Y.C.; Paik, H.D. Comparative analysis of mozzarella cheeses fortified with whey protein hydrolysates, diverse in hydrolysis time and concentrations. J. Food Sci. Technol. 2016, 53, 3566-3573. [CrossRef]

18. Angiolillo, L.; Conte, A.; Faccia, M.; Zambrini, A.V.; Del Nobile, M.A. A new method to produce synbiotic Fiordilatte cheese. Inn. Food Sci. Emerg. Technol. 2014, 22, 180-187. [CrossRef]

19. Peng, K.L.; Liu, J.X.; Ren, D.X. Effect of selenium fortification on mozzarella cheese quality. J. Anim. Sci. 2016, 94, $250-251$. [CrossRef]

20. Bermùdez-Aguirre, D.; Barbosa-Cànovas, G.V. Fortification of queso fresco, cheddar and mozzarella cheese using selected sources of omega-3 and some nonthermal approaches. Food Chem. 2012, 133, 787-797. [CrossRef]

21. Al-khalidi, B.; Chiu, W.; Rousseau, D.; Vieth, R. Bioavailability and safety of vitamin D3 from pizza baked with fortified mozzarella cheese: A randomized controlled trial. Can. J. Diet. Pract. Res. 2015, 76, 109-116. [CrossRef]

22. Lucera, A.; Costa, C.; Marinelli, V.; Saccotelli, M.A.; Del Nobile, M.A.; Conte, A. Fruit and vegetable by-products to fortify spreadable cheese. Antioxidants 2018, 7, 61. [CrossRef] 
23. Faccia, M.; Angiolillo, L.; Mastromatteo, M.; Conte, A.; Del Nobile, M.A. The effect of incorporating calcium lactate in the saline solution on improving the shelf life of Fiordilatte cheese. Int. J. Dairy Technol. 2013, 66, 373-381.

24. Sillitti, C.; Melilli, M.G.; Padalino, L.; Bognanni, R.; Tringali, S.; Conte, A.; Raccuia, S.A.; Del Nobile, M.A. Healthy pasta production using inulin from cardoon: First results of sensory evaluation. Acta Hort. 2016, 1147, 407-412. [CrossRef]

25. Padalino, L.; Costa, C.; Conte, A.; Melilli, M.G.; Sillitti, C.; Bognanni, R.; Raccuia, S.A.; Del Nobile, M.A. The quality of functional whole-meal durum wheat spaghetti as affected by inulin polymerization degree. Carbohydr. Polym. 2017, 173, 84-90. [CrossRef]

26. Buriti, F.C.A.; Cardarelli, H.R.; Filisetti, T.M.C.C.; Saad, S.M.I. Symbiotic potential of fresh cream cheese supplemented with inulin and Lactobacillus paracasei in co-culture with Streptococcus thermophilus. Food Chem. 2007, 104, 1605-1610. [CrossRef]

27. Alves, L.L.; Richards, N.S.P.S.; Mattanna, P.; Andrade, D.F.; Rezer, A.P.S.; Milani, L.I.G.; Cruz, A.G.; Faria, J.A.F. Cream cheese as a symbiotic food carrier using Bifidobacterium animalis Bb-12 and Lactobacillus acidophilus La-5 and inulin. Int. J. Dairy Technol. 2013, 66, 63-69. [CrossRef]

28. Kortei, N.K.; Odamtten, G.T.; Obodai, M.; Appiah, V.; Akonor, P.T. Determination of color parameters of gamma irradiated fresh and dried mushrooms during storage. Croat. J. Food Technol. Biotechnol. Nutr. 2015, 10, 66-71.

29. Costa, C.; Lucera, A.; Lacivita, V.; Saccotelli, M.A.; Conte, A.; Del Nobile, M.A. Packaging optimization for portioned Canestrato di Moliterno cheese. Int. J. Dairy Technol. 2016, 69, 401-409. [CrossRef]

30. Yun, J.J.; Kiely, L.J.; Kindstedt, P.S.; Barbano, D.M. Mozzarella cheese: Impact of coagulant type on functional properties. J. Dairy Sci. 1993, 76, 3657-3663. [CrossRef]

31. Tunick, M.H. Rheology of dairy foods that gel, stretch, and fractur. J. Dairy Sci. 2000, 83, 1892-1898. [CrossRef]

32. Lucera, A.; Mastromatteo, M.; Conte, A.; Zambrini, A.V.; Faccia, M.; Del Nobile, M.A. Effect of active coating on microbiological and sensory properties of fresh mozzarella cheese. Food Packag. Shelf Life 2014, 1, 25-29. [CrossRef]

33. Tungland, B.C.; Meyer, D. Non-digestible oligosaccharides (dietary fibre): Their physiology and role in human health and food. Compreh. Rev. Food Sci. Food Saf. 2002, 3, 73-92.

34. McMahon, D.J.; Motawee, M.M.; McManus, W.R. Influence of brine concentration and temperature on composition, microstructure, and yield of feta cheese. J. Dairy Sci. 2009, 92, 4169-4179. [CrossRef]

35. Ricciardi, A.; Guidone, A.; Zotta, T.; Matera, A.; Claps, S.; Parente, E. Evolution of microbial counts and chemical and physicochemical parameters in high-moisture Mozzarella cheese during refrigerated storage. LWT Food Sci. Technol. 2015, 6, 821-827. [CrossRef]

36. Juan, B.; Zamora, A.; Quintana, F.; Guamis, B.; Trujillo, A.J. Effect of inulin addition on the sensorial properties of reduced-fat fresh cheese. Int. J. Dairy Technol. 2013, 66, 1-6. [CrossRef]

37. Gammariello, D.; Conte, A.; Di Giulio, S.; Attanasio, M.; Del Nobile, M.A. Shelf life of stracciatella cheese under modified atmosphere packaging. J. Dairy Sci. 2009, 92, 483-490. [CrossRef]

38. Muslim, S.N.; Zaki, N.H.; Hussein, M.H. Purification and characterization of exoinulinase from Pseudomonas putida isolated from agricultural waste materials. J. Pure Sci. 2014, 10, 71-89. 